\title{
Democratic Government and the Building Controll Department
}

Ho Teck Tuak, PhD.

1. The United States believes that Democratic governance is the gold standard any country must adopt in governing their country. The United States even went to the extent of assassinating foreign country leaders who are deemed to not running a democratic government to replace it with a democratic government. Those countries who agree to run a democratic government would most likely have those countries leaders themselves and their inner circles enjoying complete freedom in the world. United States is therefore the principal and those allies are the franchisees. But is it acceptable to the United States if the franchisees operate as a non-democratic government for example a dictatorship government but only has its name democratic? There must be many countries that appear to be in this manner, but the United States probably has no time or energy to supervise their franchisees to make sure they are what they say they are. Would the United States consider taking on lesser franchisees and therefore is more manageable?

2. This is a case of the Government Building Controll Department wrongly approves submission of drawings for construction for three critical issues, but refuse to admit mistakes and rectify the mistakes even after hard evidence are presented to them, and appear to bully any professional engineers engaged to give second opinion that reported the mistakes have occurred. The details of the letter of complaint to the Professional Engineers and the Minister of National 1 is in Annex A. The hard evidences are from two professional engineers and six references, including the author who has advanced training in those issues, together is nine second-opinions, in Annex B to E. The mistakes are the BCD wrongly approves for the design and construction allowing Slender Columns to be built attached them to neighbour's structural load-bearing walls, allowing the foundation to be built like a see-saw system that is unstable, and allowing three and a half storeys high walls to be built but did not have drainage to drain rainwater run-off and all the run-offs pour into and encroach into neighbour's property and flooding it. After the extensive and repeated complaints to them, they appear to quietly revise the Building Regulation and ACT, making it a statutory offense for any engineer, architect, contractor, and developer who repeat those mistakes elsewhere moving forward. Meaning they appear to only now realized such mistakes are serious mistakes for those mistakes to be counted as a statutory offense that can affect life and death. But they did not admit it or go back to rectify the mistake but appear to let the neighbour victim affected by those mistakes to die. Having made those mistakes, they appear now to not extend the duty of care to the citizen and effectively also appear to breach professional ethics. Any engineers in the government or elsewhere who have no consideration for following proper building codes and standards, no consideration for human life and death, refuse to admit mistakes and do rectification even when those mistakes are being alerted to them, should be banned from practice for life. 
3. The BCD approving officer is Kwa Chin his immediate former head of department is PE Yang Kin the former CEO is Dr John t the former Minister for National $\quad$ is Kaw Boon the second former Minister for National is Lawrence the current Minister for National to is Desmond The PE for the works is PE Goh Yong from YC $\square$ Consultants, the contractor is Vincent from Rich Dimen the architect is from ACL the owner or developer is Goh Kim _. The last search I did a while ago on the internet appears to show the owner is working as an Assistant Professor teaching university students at Nanyang _University. It is where student learns ethics as part of their curriculum.

4. After a mistake has occurred and brought to the authority's attention, the right thing to do is to rectify the error made. But it appears a while ago there is a senior minister in the current era of the government who openly announces that Civil Servant must not be seen to make mistakes. This appears to mean if a mistake occurs it must not be admitted. The only person I know in this human race that does not make mistake is God himself. Any mortal will make countless mistakes in their lifetime. But as a professional, it is how to be humble enough to admit the mistake and rectify it. It appears only non-human does not know how to be humble to admit mistakes and rectify the mistakes.

5. In a typical good human resources system, once a staff makes a mistake and a serious one, it is likely he is suspended from service pending investigation, he may be subjected to micro-managing, he may be required to undergo retraining of his basic at his own expense, he may be demoted, he may be dismissed. But what appears to happen here is the staff was awarded a likely expensive government overseas scholarship using public funds to further his studies in the United States. It appears it use to be government scholarships are meant for the best and brightest. What is the signal that is being sent out to this staff and his colleague? It appears to mean making mistake, the larger it is, the bigger is the rewards.

6. In Annex E, The British Standards for Engineering Design, BS 8110 or any other International Standards, for example, British Standards-Eurocode BS EN 1992: 2004 or the American Standards ASTM, it shows that the No. 62 design and construction for their columns are Slender Columns. (The latest code use in Singapore after BS8110 is BritishEurocode BS-EN1992. The BS-EN1992 is similar to BS8110 for the design of structures and the main difference is it includes additional standards for designs requiring the use of higher concrete strength which is not applicable for this case. Engineers may choose to use BS 8110 or BS-EN1992. The latest engineering code is built from the older code and can make an older code obsolete in academia, but it does not make the older code wrong.) Slender Column is well known to good engineers to deform outwards during their loading life cycles. Even if the column is not designed slender, that is a Short Column, 
there is the existence of eccentricity of loading, which will also cause the column to deform outwards during its loading. In general, a new column, short or slender must not be attached to the existing structure, because it will cause deformation against the structure it is close to. But in this case, it is wrongly designed and constructed to be not only close to but are directly attached or abutted to neighbour structure causing damages and continuous damages.

7. In accordance with the Building ACT (Chapter 29), Part II, as attached Annex F:

\section{Application for approval of plans of building works}

5.-(1) An application for approval of the plans of any building works shall be made to the Commissioner of Building Control by the developer of those building works.

(2) An application for approval of the plans of any building works shall be accompanied by -

(c) the plans of the building works prepared in accordance with the building regulations; ]

[ 9.-(1) Every qualified person who is appointed under section 8 or 11 to prepare the plans of any building works shall -

(a) take all reasonable steps and exercise due diligence to ensure that the building works are designed in accordance with -

(i) the provisions of this Act; and

(ii) subject to section $6 \mathrm{~A}$, the requirements prescribed in the building regulations; ]

8a. In accordance with the Building Regulations 2003, Fifth Schedule, B, as attached Annex G:

[ 4. A building, including its foundation, shall be designed and constructed so that the combined dead, imposed, wind and other intended loads can be sustained and transmitted by it to the ground -

(a) safely; and

(b) without causing such deflection or deformation of any part of that building, or such movement of the ground, as will impair the stability of any part of another building or property. ] 
8b. Deflection or Deformation in engineering terms is also the same term for Displacement or Bending.

9. The Building Controll Department replied and admitted that, as attached Annex H:

[ 2 The building plans for the proposed building works at 62 Jalan

do indicate that certain structures such as the columns and defence shelter wall will be abutting the party wall between 60 and 62 Jalan

10a. Annex E shows the six references from authors from International Professional Engineers for Engineering design and construction including British Standards, American Standards, Euro codes, Singapore Standards. And it appears all these standards and references are recognised and approved for the design and construction by the Building Controll Department. From two of the typical six references, it states:

A slender column is defined as a column whose strength is reduced by second-order deformations due to horizontal displacements.

The column has a horizontal deflection $\mathrm{D}$ along the span because of the applied loading.

Slender columns are susceptible to the following two effects that might lead to an instability failure,

Second-order (P - .D.) effects result in an increase in the bending moments developed in a column caused by lateral deflections (sidesway).

10b. This horizontal deflection or lateral deflections (sideways) as mentioned, refers to in the BCD Regulation, is the deflection or deformation action against another building or property.

11a. Annex $B$ to $D$, shows three Professional Engineers that are engaged by No. 60 to produce Professional Engineers reports for this case. And Annex $E$ shows six references from International Professional Engineers that describe the mistakes of using the slender columns for the No 62 building. All three engineers reports and six eminent engineers and standards body show that the No. 62 Slender Columns attaching to the No. 60 Structure is causing deformation against the No. 60 structure and is wrong and is a design mistake. And the damages from the deformation have already occurred, there is photographic evidence recorded of cracks that grow when the No. 62 started to occupy their second floor and are reported in the second Professional Engineer report, and these damages are continuous as long as the columns remain attaching. Therefore, the approval for such design and construction is wrong and a mistake. These deformations 
are the deformations actions as stated in the Regulations and it contravene the Building Regulation 2003, SN: 4.

11b. But a reply from the Ministry of National

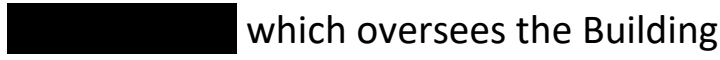
Controll Department, states that as attached Annex I:

[ We would like to clarify that the works carried out at your neighbours' unit, No. 62 Jalan (No. 62), do not contravene the Building Control Act or Regulations. ]

11c. Does this appear to be Civil Servant must not be seen to make mistakes? Does it ever occur that there are people around who do know and do know if mistakes are made?

12a. In Annex I, the Ministry reply states:

[ the Qualified Person (QP) appointed for the construction works at No. 62 has certified that the overall structural stability of your unit will not be affected by the works at No. 62. ]

12b. The Qualified Person(QP) for No. 62 has never viewed the engineering drawings of No. 60 structure, he never design for No.60 structure, he, therefore, does not know what the structure of No.60 is or what it has become since it was built a long time ago. So, how would he know as mentioned in the Ministry's reply, "the overall structural stability of your unit will not be affected." It is a groundless statement made. It is hearsay. It is unbelievable that Engineering reporting to a high level has become easily accepted as it is now.

13a. In the Building Control ACT, Chapter 29, Part V, in Annex J, it states:

[29.- (1) A structural engineer shall not be appointed by the Commissioner of Building Control or owner of a building for the purpose of carrying out an inspection of a building under section 28 if the structural engineer has any professional or financial interest in the building.

(2) A structural engineer shall be regarded as having a professional or financial interest in any building if -

(a) he is or has been responsible for the design or construction of the building or any of the building works in any capacity except building works relating to the alterations of the building which - ] 
13b. In this case it is a dispute between No 60 and the No.62 Professional Engineer or Qualified Person for their design. It is a dispute between No.60 against the BCD approval. Therefore, it appears the only correct thing to do to avoid conflict of interest to any party is to engage another Professional Engineer to look into the complaints. But it appears the BCD asks the No.62 Qualified Person to be his own judge for his own mistakes as in point 12a above. And it appears the Qualified Person said he did not make any mistakes and without any supporting documents. Does this contravene the Building ACT, Part V, clause 29(1) \& (2)?

14a. In Annex I, the Ministry reply states:

[ the builder has offered to repair the damages with a one-year defects liability period. ]

14b. The third professional engineer has been engaged to produce a report on how to rectify the mistakes of No. 62 and repair the No. 60 . The builder went through the report in front of a lawyer and agrees with the report. But afterward, he refuses to sign to honour he will do the works as in the report. Does the Ministry knows the statement made by the builder to them is false?

15. In any society, there are rich and poor people. Some people have more resources than others. In a truly democratic government like the United States, both the rich and poor, the have and have nots, are equally protected under the constitution. The rich cannot use their more money they have to bully the poor. If the rich do wrong to the helpless poor, the poor cannot afford to engage a lawyer or buy court times to sue the rich. But in America, a lawyer can offer his service to the poor and agree that he will only collect his fee from the case if he wins the court case. But here such an arrangement is illegal. So, the poor are indeed helpless if the richer take advantage of them.

16. I went to see the Minister of National Kwa Boon He said if your neighbour damages your building if you have the resources you sue them. If you do not have the resource you just have to leave with it. I was completely stunned and taken aback in disbelief of what I was hearing. It appears it is unjust. He appears to spread inequality among the people. What he appears to refer to is that engaging a lawyer and fight it out in court will cost a very large sum of money. He further said that it is cheaper to get a second opinion. And he appears to say maybe the second opinion will tell you your suspicion is unfounded and that every design is correct all along. He said the second opinion refers to engaging a Professional Engineer to assess the case, which is much cheaper. He appears to say that if the second opinion reported everything is fine then he does not need to do anything further, and if the second opinion does report a mistake, he will do something as he is the Minister for the BCD. And that something appears to be to 
take action against the approving officer from $B C D$ and issue an order for the builder to rectify the mistake as it is against the Regulation.

17. I engage a first Professional Engineer and later the second Professional Engineer. Both the Professional Engineers reported that indeed mistakes had occurred. Therefore, the BCD should not have approved such design and construction. I went to give the first report to the Minister. He appears not too happy after I told him what I have to give him. I quietly finish the meeting and left. Many months later while waiting for his order, but nothing came. Later I came to know the Professional Engineer who works for Mott MacDon a UK-based firm and his immediate head of department appears to be forced to resign from the company. And the UK-based company appears to hold many building contracts with the government. And there was no follow-up for the rectification and repair orders. The Professional Engineer later appear to tell me he does not want to continue to work for this case and asks me to engage another Professional Engineer. The second Professional Engineers after submitting the report to the BCD, later appear to also shouted over the phone that he does not want to continue working on this case and bang down the phone.

18. It appears that in a democratic government and as in the constitution, the pledge that everyone takes and is an oath of allegiance to the flag is: We, the citizen to build a democratic society based on justice and equality...... . But it appears here, in reality, the richer has an advantage over the poorer. It appears a Minister is in the perfect position to do changes if something is found to be against the constitution. But it appears he does not and appears to continue to spread inequality. And it appears it is the majority who is likely the poorer who voted for him to be in his position. But it appears the minority the richer ones are the more advantageous ones.

19a. The BCD produces a 29 pages cartoonish document called: Be Good Neighbours as in Annex K. It spells out for construction or renovation what a good neighbour should and should not do which affects its neighbours. The BCD appears to tell me this document is not a regulation but a suggestion. Any builder can choose to comply or choose not to comply with the content. On Pg 10, it states:

[ Your contractor should not use the existing party wall as formwork or support for construction works as this may affect the stability of the party wall. An independent formwork or support system should be used. ]

19b. If the builder chooses to ignore this document and uses the neighbour party wall as formwork, after the concrete is poured into the formwork, and after the concrete is hardened, and after the timber formwork mould is removed, the hardened concrete become stuck to and attached or abutted directly the neighbour's party wall, that is the happening in this case. This hardened concrete when loaded will cause deformation or 
deflection against the neighbour's party wall. These deformation actions, therefore, contravene the Building Regulation 2003, SN 4, as mentioned above for this case. Therefore, the builder can only choose not to allow to do. Therefore, this suggestive statement is an error and should not be a suggestion to do or not to do but is required to be a mandatory not allow to do.

20a. In the same typical paragraph, it states:

[ Hacking the existing wall to create a recess to embed new walls, columns or beams is not allowed, except where approval has been given by $\mathrm{BCA}$. ]

20b. Is the "not allowed" in this document a suggestion or an order to comply?

21. In engineering, if work needs to do, there is a contract to sign and there is usually a significant amount of money to spend, there is effort required in committing to do and there is making way for the work. Therefore, if something needs to do it has to be mandatory to do. If something is not required to do why ask people to do it. Such a document of suggestions that are outside of the ACT and Regulations, causes confusion and costly disputes.

22a. In the Building Controll ACT, Chapter 29, Part VI, 32, in Annex L, it states:

[ (3) No matter or thing done by the Commissioner of Building Control or by any public officer shall, if it were done bona fide for the purpose of carrying out the provisions of this Act, subject the Commissioner of Building Control or the public officer personally to any action, liability, claim or demand. ]

22b. It appears that this means that the $B C D$ cannot be sued to win the case however right the citizen is and however wrong the BCD is. It appears any citizen can sue the BCD and spends a large amount of money to buy a lawyer and court times to do so, but the citizen will lose the case however right the citizen is and the BCD will win the case however wrong the $B C D$ is.

23. It appears that recently the government has changed a rule for the number of lawyers the government can engage to protect its interests. It appears that they can engage four lawyers or so. But does any case require engaging four specialist lawyers? It appears that it is likely the citizen who sue the government will usually engage one specialist lawyer. Therefore, should the government win the case against the citizen, the citizen is required to compensate the government for four numbers of the lawyers' fees. It appears this rule is more a deterrent to any citizen who intends to sue the government for wrongdoings. 
24. It appears that recently there is a foreign ambassador from a foreign country who was involved in a local motor vehicle accident and kill some pedestrians. The ambassador makes use of his immunity passport to escape and leave the country and did not answer to prosecution. It appears a minister flew to the home country of the ambassador and insisted that the ambassador admit his mistakes and faces prosecution. It appears the reason given was if the ambassador is not prosecuted for his mistake there will be backlashes from the minister's citizen voters.

25. It appears there is a large group of people and inner circles including of general ranks who do not have to admit mistakes made and are immune from admitting mistakes made and the immunity is more powerful than the Immunity Passport for foreign countries ambassadors accorded by the Geneva Convention. It appears this group can do whatever they like rightly or wrongly, legally or illegally, and can get away with it.

26. It appears a dictator and his inner circles can do whatever they like rightly or wrongly, legally or illegally, and can get away with it.

27. Is this still a country? 
Main Annex:

https://osf.io/hdpxi/?view only=b5a1949556ec4623a8ddc49128ef9d39 or https://t2m.io/TcPxbxn4

\begin{tabular}{|c|c|}
\hline Annex & URL \\
\hline Annex_A_Letter_to_PED-Min-pdf-P.pdf & $\begin{array}{l}\text { https://mfr.osf.io/render?url=https://osf.io/zn9ch/?direct\%2 } \\
\text { 6mode=render\%26action=download\%26mode=render or } \\
\text { https://t2m.io/azEGPhr }\end{array}$ \\
\hline $\begin{array}{l}\text { Annex_B_Profesional_Engineer_Report_1-pdf- } \\
\text { P.pdf }\end{array}$ & $\begin{array}{l}\text { https://mfr.osf.io/render?url=https://osf.io/h6fs4/?direct\%2 } \\
\text { 6mode=render\%26action=download\%26mode=render or } \\
\text { https://t2m.io/QpBD7CVP }\end{array}$ \\
\hline $\begin{array}{l}\text { Annex_C_Professional_Engineer_Report_2-pdf- } \\
\text { P.pdf }\end{array}$ & $\begin{array}{l}\text { https://mfr.osf.io/render?url=https://osf.io/5x6av/?direct\%2 } \\
\text { 6mode=render\%26action=download\%26mode=render or } \\
\text { https://t2m.io/uWffpwNT }\end{array}$ \\
\hline $\begin{array}{l}\text { Annex_D-Professional_Engineer_Report_3-pdf- } \\
\text { P.pdf }\end{array}$ & $\begin{array}{l}\text { https://mfr.osf.io/render?url=https://osf.io/nywe9/?direct\% } \\
\text { 26mode=render\%26action=download\%26mode=render or } \\
\text { https://t2m.io/ZDtWFp91 }\end{array}$ \\
\hline Annex_E1-E6.pdf & $\begin{array}{l}\text { https://mfr.osf.io/render?url=https://osf.io/r23xq/?direct\%2 } \\
\text { 6mode=render\%26action=download\%26mode=render or } \\
\text { https://t2m.io/OWkEEZbV }\end{array}$ \\
\hline $\begin{array}{l}\text { Annex_F_Building_Control_Act_Clause_5\&9- } \\
\text { pdf-P.pdf }\end{array}$ & $\begin{array}{l}\text { https://mfr.osf.io/render?url=https://osf.io/w5zbf/?direct\%2 } \\
\text { 6mode=render\%26action=download\%26mode=render or } \\
\text { https://t2m.io/vHwFGGTH }\end{array}$ \\
\hline $\begin{array}{l}\text { Annex_G_Building Control Regulations } \\
\text { 2003_FIFTH_SCHEDULE_B-pdf-P.pdf }\end{array}$ & $\begin{array}{l}\text { https://mfr.osf.io/render?url=https://osf.io/ga2xf/?direct\%2 } \\
\text { 6mode=render\%26action=download\%26mode=render or } \\
\text { https://t2m.io/gW6CVsv3 }\end{array}$ \\
\hline Annex_H_BCD_Email_Reply-pdf-P.pdf & $\begin{array}{l}\text { https://mfr.osf.io/render?url=https://osf.io/mcae5/?direct\% } \\
\text { 26mode=render\%26action=download\%26mode=render or } \\
\text { https://t2m.io/vThzV4vu }\end{array}$ \\
\hline Annex_I-MND_EMail_Reply-pdf-P.pdf & $\begin{array}{l}\text { https://mfr.osf.io/render?url=https://osf.io/ntc7v/?direct\%2 } \\
\text { 6mode=render\%26action=download\%26mode=render or } \\
\text { https://t2m.io/kM3RfxXY }\end{array}$ \\
\hline $\begin{array}{l}\text { Annex_J_Building_Control_Act_PART_V_29-pdf- } \\
\text { P.pdf }\end{array}$ & $\begin{array}{l}\text { https://mfr.osf.io/render?url=https://osf.io/25ntr/?direct\%2 } \\
\text { 6mode=render\%26action=download\%26mode=render or } \\
\text { https://t2m.io/yzDTHVAx }\end{array}$ \\
\hline Annex_K_Be_Good_Neighbours_pp10-pdf-P.pdf & $\begin{array}{l}\text { https://mfr.osf.io/render?url=https://osf.io/7nbgd/?direct\%2 } \\
\text { 6mode=render\%26action=download\%26mode=render or } \\
\text { https://t2m.io/6sp8XmkY }\end{array}$ \\
\hline $\begin{array}{l}\text { Annex_L_Building_Control_Act_PART_VI_32-pdf- } \\
\text { P.pdf }\end{array}$ & $\begin{array}{l}\text { https://mfr.osf.io/render?url=https://osf.io/dvs9j/?direct } \% 26 \\
\text { mode=render\%26action=download\%26mode=render or } \\
\text { https://t2m.io/6VMvnceN }\end{array}$ \\
\hline
\end{tabular}

